\title{
ЗАСТОСУВАННЯ ВІЗУАЛЬНОГО АНАЛІЗУ АРТЕРІАЛЬНИХ ОСЦИЛОГРАМ В ПРАКТИЦІ СІМЕЙНОГО ЛІКАРЯ
}

\author{
○Д. В. Вакуленко ${ }^{1}$, Л. О. Вакуленко ${ }^{1}$, О. В. Кутакова²
}

'ДВНЗ «Тернопільський державний медичний університет імені І. Я. Горбачевського мОз України» ${ }^{2}$ Житомирська ЦРЛ

PЕЗЮМЕ. Запропоновані авторами інформаційні технології візуального аналізу артеріальних осцилограм значно підвищують інформативність процедури вимірювання артеріального тиску. Можуть бути використані для раннього виявлення донозологічних і преморбідних станів та функціональних резервів системи кровообігу, контролю ефективності лікування, які допоможуть лікарю більш ефективно спланувати профілактичний, діагностичний та терапевтичний процес.

КлючОВІ СЛОВА: артеріальна осцилографія; візуальний аналіз осцилограм.

Вступ. Основну роль у організації та проведенні всіх видів профілактики захворювань відіграє лікар загальної практики (сімейної медицини). У першу чергу це відноситься до захворювань ССС, які реєструється у $3 / 4$ населення України, а в $62,5 \%$ випадків вони $€$ причиною смерті [1]. Значною мірою благополуччя кровообігу залежить від стану судин - «периферійного серця». Одним із методів їх оцінки $\epsilon$ артеріальна осцилографія, яка дає можливість розширити інформацію про стан адаптаційної здатності серцево-судинної системи, периферійних судин, вегетативної та центральної нервової систем [2].

Мета досліджень - дати інформацію сімейному лікарю щодо методів візуального аналізу артеріальних осцилограм.

Матеріал та методи дослідження. Робота базується на аналізі 1440 артеріальних осцилограм 446 осіб різного віку та стану здоров'я, отриманих за допомогою електронного вимірювача артеріального тиску ВАТ 41-2 (виробник «ІКСТЕХНО»), здатного експортувати отримані значення для подальшого аналізу. Аналіз виконували за допомогою запропонованих авторами інформаційних технологій [2]. За ступенем відхилень від запропонованої авторами норми осцилограми поділені на 5 типів [2].
Результати й обговорення. Аналіз досліджень показав, що для осцилограми першого типу (рис. 1) притаманне наступне.

I. Форма осцилограми. 1. Ритмічність осциляцій, поступове рівномірне зростання їх амплітуд, досягнення максимуму та зниження до кінця реєстрації. 2. Збереження в процесі зростання компресії декількох однакових за амплітудою максимальних осциляцій (в період початку повного перетискання судин під час діастоли). 3. Поява піків максимальних екстремумів слідом за мінімальними. 4. Більш виражене зростання амплітуди осциляцій на висхідній частині осцилограми - показник діастолічного, зниження на низхідній - систолічного тиску.

II. Характер окремих осциляцій у різних фазах компресії. 1. Амплітуда кожної пульсової хвилі пропорційна змінюваному під впливом тиску в манжеті просвіту магістральної артеріальної судини: поступово зростає, досягає максимуму і поступово знижується. 2. Вершини верхніх екстремумів загострені. На початку компресіїі х кут більший, в процесі зростання компресії-спочатку зменшується, а потім наближається до нуля: верхня частина катакроти значно наближається до анакроти або збігається 3 нею. 3. Площа висхідної частини менша, низхідної більша. Вони співвідносяться між собою як 1 до 6.

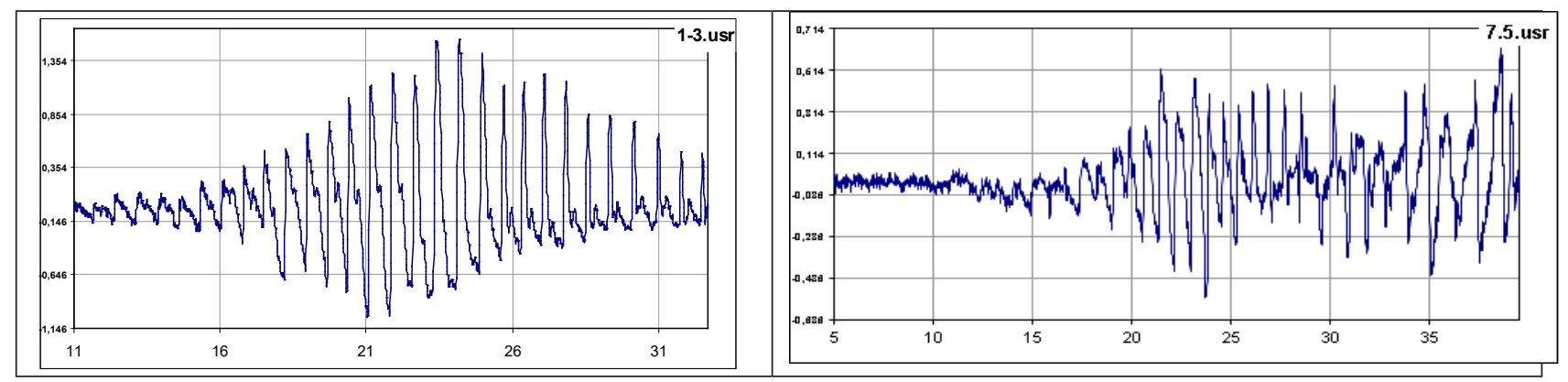

Рис. 1. Осцилограма судин плеча обстежених М., 20 років (зліва, 1-й тип) та Р., 20 років (справа, 4-й тип). По осі $X$ - час реєстрації окремих осциляцій (c), по осі Y - значення коливань тиску в манжеті під впливом судинної стінки артерії (мм рт. ст.) 
Огляди літератури, оригінальні дослідження, погляд на проблему, короткі повідомлення

3. Тривалість фази повільного вигнання крові в процесі збільшення компресії поступово зростає, фаза діастоли - скорочується.

III. Наявність, локалізація, величина дикротичної та додаткових хвиль на окремих осциляціях. 1. На висхідній частині осциляції додаткові хвилі відсутні. 2. На низхідній частині осциляцій, в кінці систоли, реєструється дикротична хвиля. На початку компресії вона розміщена на середній частині катакроти, зникає при максимальній амплітуді осциляцій. В процесі наростання компресії з'являється знову, але вже на нижній частині катакроти, і в кожній наступній пульсації поступово наближається до її нижнього краю. Амплітуда дикротичної хвилі при цьому зростає. 3. В процесі зростання компресії на низхідній частині осциляцій слідом за дикротичною хвилею реєструються дрібні однотипні додаткові хвилі. 4. Повну компресію судин (або систолічний тиск) можна визначити не лише за стрімким зменшенням амплітуди осциляцій, але і за зникненням дикротичної хвилі на низхідній частині. 5. Однотипні дрібні осциляції в період, коли судина повністю стиснута, $\epsilon$ результатом дії інерційних сил. Вони утримуються до появи наступного гідравлічного удару.

На рисунку 1 справа розміщена осцилограма особи, що не скаржилась на стан здоров'я (4-й тип). При її візуальному аналізі привертають увагу відхилення від норми за усіма критеріями. Ця особа потребує негайного поглибленого обстеження.

\section{ЛІТЕРАТУРА}

1. Булич Э. Г. На пути познания сущности здоровья: достижения и опасности / Э. Г. Булич, И. В. Муравов // Довкілля та здоров'я. - 2011. - № 1 (56). - С. 36-44.

2. Вакуленко Д. В. Інформаційна система морфологічного, часового, частотного та кореляційного аналізу артеріальних осцилограм у фізичній реабілітації :

\section{REFERENCES}

1. Bulych, E. G., Muravov, I.V. (2011). Na puty poznanyya sushchnosty zdorovya: dostyzhenyya i opasnosti [In essence WAYS cognition health: achievements and danger]. Dovkillia ta zdorovia - Environment and Health, 1 (56), 36-44 [in Russian].

2. Vakulenko, D.V. (2015). Informatsiina systema morfolohichnoho, chasovoho, chastotnohotakorelyatsiinoho analizu arterialnykh ostsylohram u fizychniy reabilitatsii:
Результати й обговорення. Загальний аналіз осцилограм 110 осіб віком 20-25 років без скарг на стан здоров'я (за аналогією з фізіологічною інтерпретацією електрокардіосигналу [3]) засвідчив наступне: 1 тип, здоровий (оптимальна адаптація) зареєстровано у 8,8 \% обстежених, 2, практично здоровий (напружена адаптація) - у 44,1 \%, 3, умовно здоровий (перенапруження адаптації) - у 23,5 \%, 4, стан передхвороби (зрив адаптації) - у 20,7 \%, 5, хворий (адаптація до порушень) - у 2,9 \%. Таким чином, у обстежених найчастіше зустрічався 2 тип градації - напруження адаптації. Особи з 3 типом осцилограм потребують профілактичного, з 4 - більш поглибленого обстеження, з 5 - ще і лікування. Це підтверджує вказівки Булич Е. [1], що навіть серед тих підлітків, які визнані лікарями здоровими, лише третина має середній і високий рівень соматичного здоров'я. Діагностичні можливості методу більш перспективні, потребують подальшого удосконалення.

Висновки. Запропоновані авторами інформаційні технології візуального аналізу артеріальних осцилограм значно підвищують інформативність процедури вимірювання артеріального тиску. Вони можуть бути використані для раннього виявлення донозологічних і преморбідних станів, функціональних резервів системи кровообігу, контролю ефективності лікування, які допоможуть лікарю більш ефективно спланувати профілактичний, діагностичний та терапевтичний процес.

монографія / Д. В. Вакуленко. - Тернопіль : ТДМУ, 2015. -212 c.

3. Баевский Р.М. Оценка адаптационных возможностей организма и риск развития заболеваний / Р. М. Баевский, А. П. Берсенева. - М. : Медицина, 1997. -265 c.

monohrafiia [Information System morphological, time, frequency and correlation analysis of arterial oscillograms in physical rehabilitation: Monograph]. [in Ukrainian].

3. Baevskyy, R.M., Berseneva, A.P. (1997). Otsenka adaptatsyonnykh vozmozhnostey organizma i risk razvitiya zabolevaniy [Assessment of adaptive capabilities of the body and the risk of developing diseases]. Meditsyna Medicine. 265. 
ПРИМЕНЕНИЕ ВИЗУАЛЬНОГО АНАЛИЗА АРТЕРИАЛЬНЫХ ОСЦИЛЛОГРАММ В ПРАКТИКЕ СЕМЕЙНОГО ВРАЧА

СД. В. Вакуленко ${ }^{1}$, Л. О. Вакуленко ${ }^{1}$, О. В. Кутакова²

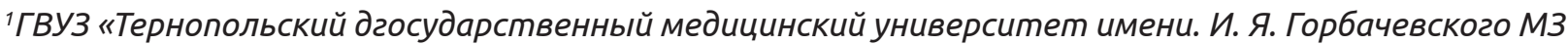
Украины»

${ }^{2}$ Житомирская ЦРБ

РЕзЮМЕ. Предложенные авторами информационные технологии визуального анализа артериальных осциллограмм значительно повышают информативность процедуры измерения артериального давления. Могут быть использованы для раннего выявления донозологических, преморбидных состояний, функциональных возможностей системы кровообращения, контроля эффективности лечения, которые помогут врачу более эффективно спланировать профилактический, диагностический и терапевтический процесс.

КЛЮЧЕВЫЕ СЛОВА: артериальная осциллография; визуальный анализ артериальных осциллограмм.

\section{ANALYSIS OF VISUAL ARTERIAL OSCILLOGRAMS IN FAMILY DOCTOR PRACTICE @D. V. Vakulenko', L. O. Vakulenko', O. V. Kutakova² \\ '1. Horbachevsky Ternopil State Medical University ${ }^{2}$ Zhytomyr Central District Hospital}

SUMMARY. Offered by author information technology of morphological analysis of waveforms, the introduction of analytical treated for clinical interpretation of the results, evaluation and decision-making to doctors significantly increases the information content of the procedure of blood pressure measurement; can be used for early detection and prenosological premorbid state and functional reserve of the circulatory system, help more effectively to plan preventive, diagnostic and therapeutic process.

KEY WORDS: arterial oscillography; morphological analysis of waveforms. 